clusions of the Ministry as to the causes to which these accidents are attributed. First, only one cause has been assigned to each accident, although the blame should be distributed in various proportions between road conditions, the road user, the vehicle and both parties involved in the collision. Secondly, the system of police reports on road accidents is often inadequate. Thirdly, the vehicles are sometimes so damaged that it is impossible to say whether they were defective or not. Fourthly, the Committee does not agree with the general principle on which the Ministry proceeds, that even if the condition of the roads and cars was unimpeachable the total of accidents would not be appreciably affected. The Committee believes that segregation of drivers, cyclists and pedestrians on the main roads must come and that the attainment of this ideal is essential if road safety is to be ensured. The highway code should be revised and it should be given the force of law. Witnesses before the Committee were strongly of opinion that an extensive and persistent campaign of educational propaganda should be undertaken and that it should be aimed at every class of road user. The improvement of main roads and the construction of now roads should be carried on simultaneously. 'Lay-byes' and 'draw-ins' should be made on every few miles of highway. The costly system of erecting kerbs should cease and guard posts should be erected 18 inches outside the edges of roads, at suitable intervals, sloping outwards at an angle of $15^{\circ}$ from the vertical and provided with reflectors. Many other useful suggestions are made and we hope that some of them will be adopted.

\section{The National Botanic Gardens of South Africa}

IN September 1938, the National Botanic Gardens of South Africa, at Kirstenbosch, and the Botanical Society celebrated their silver jubilee, and in the close of the year was produced a special number of the Journal of the Botanical Society with some very fine photographs, which show something of the beauty of the Kirstenbosch Botanic Garden with its ideal site on the slopes of Table Mountain. The number contains a brief note by the editor, Prof. R. H. Compton, upon the history of the Gardens, the site of which was selected in 1913 by the late Dr. Pearson, then professor of botany at the South African College. On a motion by Sir Lionel Phillips, the House of Assembly and the Senate passed unanimously in that year a motion that Kirstenbosch, bequeathed to the people of the Cape by Cecil Rhodes as part of his great Groot Schuur Estate, should be granted by the Government as the site of the National Botanic Gardens. The Government consented, making an annual grant towards its support, and at the same time the Botanical Society was formed, with some three hundred subscribers, to enlist public support for the new venture. The early onset of the Great War and the subsequent financial depression has caused delay, but the Director can record many striking indications of progress in the Gardens, and the Botanical Society has now nearly 2,000 members enrolled.

\section{Biology in Education}

The Educational Advisory Board of the British Social Hygiene Council is attempting to give a new orientation to the teaching of biology by bringing it more into touch with individual needs and social problems of to-day. With this aim in view, a Summer School has been arranged at Keble College, Oxford, during July 28-August 4. The School is primarily intended for teachers and others who are concerned with the place of biology in education, but member. ship will be open to anyone who is interested in the biological problems of modern human life. The inaugural address will be given by Prof. J. Scott Watson. One section of the School will deal with current problems in social biology and their repercussions on the school-child, and another section will be concerned with problems of personal growth and development. These sections will be contributed to by lecturers with considerable experience in their particular fields. The third course will include lectures on subjects of topical interest by prominent workers in biological research, including $\mathrm{Mr}$. C. S. Elton, Dr. S. Zuckerman, Dr. H. N. Sinclair and Dr. Keith Murray. There will be considerable opportunities for discussion, while excursions to places of academic interest are being arranged. Further particulars can be obtained from Mr. 'T. H. Hawkins, Education Officer, British Social Hygiene Council, Tavistock House South, Tavistock Square, London, W.C.1.

\section{The League of Nations Union}

A LEAflet issued by the League of Nations Union for the assistance of teachers preparing to address their pupils on Empire Day emphasizes the part played by representatives of the British Empire in drafting the Covenant of the League, which is described as a first attempt to apply on a world scale the ideals of democratic government common to the British Commonwealth of Nations and the United States of America. It suggests the possibility of a federation of these and all other democratic States and the sharing of the control of colonial territories and our responsibilities for the development of colonial peoples to full nationhood. The League of Nations Union's arrangements for the summer include: (a) for schoolboys and schoolgirls, 'Nansen Pioneer' camps in Devon, Shropshire and Peeblesshire and a summer school at Geneva, and $(b)$ for educational administrators and teachers, a conference to be held partly at Geneva, where members will attend the lectures and discussions of the Geneva Institute of International Relations, and partly at a mountain chalet.

\section{The International Seismological Summary}

THe April, May and June 1933 number of the International Seismological Summary has just come into the hands of those recipients who previously stated their wish to have copies straight from the press rather than wait until the annual set could be prepared and bound. This number consists of 148 